\title{
Postępowanie o stwierdzenie zgonu na tle akt Sądu Grodzkiego w Krakowie w latach 1945-1950
}

\section{WSTĘP}

Po zakończeniu II wojny światowej ustalenie i zarejestrowanie zgonów milionów obywateli stanowiło poważny problem społeczny. Rodziło to niepewność w sferze prawnej osób i związanych z nimi stosunków prawnych, powodując zarazem uszczerbek w prawach poszczególnych podmiotów oraz godząc w pewność obrotu prawnego. W celu rozwiązania problemów prawnych wynikających z faktu niesporządzenia aktu zgonu powołano instytucję stwierdzenia zgonu ${ }^{1}$.Wydanie przez sąd postanowienia o stwierdzeniu zgonu zastępowało akt zgonu, który był niezbędny do uporządkowania spraw po zmarłej osobie.

Bazę źródłową niniejszej publikacji stanowią akta spraw o stwierdzenie zgonu, które toczyły się przed Sądem Grodzkim w Krakowie w latach 1946-1950. Badania opierają się na analizie źródeł archiwalnych, które są podstawą ustalania faktów służących historycznej syntezie. Archiwalia te stanowią przejmujące źródło ludzkiego nieszczęścia, spowodowanego okrucieństwem wojny. Liczba spraw wniesionych w analizowanym okresie świadczy o skali problemu. Sąd Grodzki w Krakowie rozpatrywał wówczas około pięciu tysięcy spraw o stwierdzenie zgonu. Ze względu na obszerność materiału źródłowego szczegółowej analizie poddano więc tysiąc akt, wyselekcjonowanych w taki sposób, aby w największym stopniu

${ }^{1}$ Oprócz instytucji stwierdzenia zgonu powstała instytucja uznania za zmarłego, która stosowana była w przypadku zaginięcia osoby fizycznej po upływie określonego prawem czasu od jej zaginięcia. Autorka przeprowadziła badania archiwalne dotyczące uznania za zmarłego, które wykorzystała w rozprawie doktorskiej. Jej monografia Uznanie za zmarlego $w$ świetle akt Sadu Grodzkiego w Krakowie w latach 1946-1950 ukazała się drukiem w 2020 r. 
móc zrealizować założenia badawcze. Pod uwagę wzięto te akta, w których można było znaleźć informacje o dużej wartości badawczej. Wszystkie zachowane akta spraw o stwierdzenie zgonu znajdują się w Archiwum Narodowym w Krakowie, przy ulicy Grodzkiej 52.

Warto zaznaczyć, że wyniki badań naukowych dotyczących akt spraw o stwierdzenie zgonu, które toczyły się przed Sądem Grodzkim w Krakowie, nie były dotąd publikowane. W literaturze nie ma również kompleksowych opracowań tego tematu. W związku z tym niniejsza publikacja stanowi nowatorskie ujęcie problematyki związanej z sądowym stwierdzeniem zgonu.

\section{INSTYTUCJA STWIERDZENIA ZGONU}

Po II wojnie światowej instytucja stwierdzenia zgonu znajdowała zastosowanie, gdy śmierć osoby była niewątpliwa, jednak z różnych przyczyn nie został sporządzony akt zgonu². Najczęstszą przyczyną tego był brak zwłok lub niemożność ich odnalezienia ${ }^{3}$. Dotyczyło to również wypadków, w których zwłoki zostały odnalezione po upływie dłuższego czasu od chwili śmierci. W okresie powojennym miało to miejsce $\mathrm{w}$ razie zidentyfikowania zwłok złożonych w grobach zbiorowych ${ }^{4}$. Postępowanie o stwierdzenie zgonu mogło być wszczęte jedynie wówczas, gdy mimo niesporządzenia aktu zgonu śmierć danej osoby była absolutnie pewna ${ }^{5}$. W tych wypadkach wydanie postanowienia o stwierdzeniu zgonu miało zastąpić akt zgonu, który był niezbędny do uporządkowania spraw po zmarłej osobie ${ }^{6}$. Mogła także zaistnieć sytuacja, w której odnaleziono zwłoki danej osoby, ale akt zgonu nie został sporządzony na skutek zakłócenia działalności urzędów stanu cywilnego bądź niemożności stwierdzenia zgonu przez uprawnioną osobę, np. podczas katastrofy czy wojny, i bez uprzedniego wystawienia karty zgonu doszło do pochowania zwłok ${ }^{7}$. Sytuacje takie obecnie zdarzają się bardzo rzadko, jednak częste były podczas II wojny światowej, głównie z powodu czasowego zawieszenia

2 R. Longchamps de Bérier, Wstęp do nauki prawa cywilnego, Lublin 1922, s. 100; T. Dominowski, Z zagadnień uznania za zmarlego, „Zeszyty Naukowe Uniwersytetu Łódzkiego” 1957, nr 6, s. 219; W. Zylber, Unifikacja przepisów o uznaniu za zmarłego i stwierdzeniu zgonu, „Państwo i Prawo" 1946, nr 1, s. 46; J. Górski, Wstęp do nauki prawa cywilnego, Poznań 1947, s. 29; W. Górecki, E. Kitłowski, Prawo cywilne, Warszawa 1974, s. 29.

3 J. Gwiazdomorski, Dwa domniemania. Księga pamiątkowa dla uczczenia pracy naukowej K. Przybyłowskiego, Kraków 1965, s. 97; S. Garlicki, Domniemanie z art. 5 pr. rodz. w razie uznania męża za zmarkego, „Przegląd Notarialny” 1948, nr 6, s. 55.

${ }^{4}$ W. Zylber, Unifikacja przepisów..., s. 44;. A. Wolter, Postępowanie w sprawie uznania za zmartego i stwierdzenie zgonu, „Demokratyczny Przegląd Prawniczy” 1946, nr 4-5, s. 26.

5 A. Wolter, Postępowanie w sprawie..., s. 26.

${ }^{6}$ T. Dominowski, Z zagadnień uznania..., s. 219.

7 A. Bądkowski, Sąd w obliczu zagadnienia śmierci, „Demokratyczny Przegląd Prawniczy” 1948, nr 8, s. 10. 
działalności urzędów stanu cywilnego w miejscowościach okupowanych lub znajdujących się na linii frontu ${ }^{8}$. Dotyczyło to zwłaszcza milionów ludzi zagazowanych w hitlerowskich obozach koncentracyjnych zaraz po przywiezieniu, bez objęcia ich ewidencją obozową. Nieprowadzenie ewidencji było często praktyką celową. Równie częstym zjawiskiem było niszczenie rejestrów pomordowanych w obozach koncentracyjnych, obozach pracy czy obozach internowania NKWD. Dotyczyło to także zgonów żołnierzy, zwłaszcza z oddziałów partyzanckich oraz ofiar masowych akcji ludobójstwa ${ }^{9}$. Skalę tego zjawiska zwiększały jeszcze działania okupantów zmierzające do zatarcia śladów zbrodni, np. poprzez nieprowadzenie ewidencji zgonów ${ }^{10}$. W literaturze uważa się, że śmierć osoby była „niewątpliwa” nie tylko wtedy, gdy istnieli naoczni świadkowie zgonu, ale także wtedy, gdy okoliczności konkretnego wypadku, przy uwzględnieniu doświadczenia życiowego, uzasadniały pełne przekonanie o zgonie danej osoby ${ }^{11}$.W przypadku niesporządzenia aktu zgonu osoby zaginionej jedyną drogę (oprócz uznania za zmarłego) do zarejestrowania śmierci w aktach stanu cywilnego stanowiło sądowe stwierdzenie zgonu. Wówczas podstawą sporządzenia aktu zgonu było postanowienie sądu stwierdzające zgon danej osoby ${ }^{12}$. Sądowe stwierdzenie zgonu wywoływało skutki cywilnoprawne odpowiadające skutkom rzeczywistej śmierci ${ }^{13}$. Postanowienie sądu stwierdzające zgon miało pozwolić na zarejestrowanie aktu zgonu w przypadkach, gdy było to niemożliwe w normalnym trybie ${ }^{14}$. Orzeczenie sądu stwierdzające zgon danej osoby miało charakter deklaratoryjny, tj. potwierdzało jedynie istnienie określonego stanu prawnego; orzeczenie deklaratoryjne wywierało skutki ex nunc - sąd nie dokonywał zmian w sferze prawnej osoby, tylko stwierdzał fakt niewątpliwej śmierci; skutki tego stwierdzenia sięgały wstecz do ustalonej daty zgonu ${ }^{15}$.

\section{PODSTAWY PRAWNE STWIERDZENIA ZGONU}

Regulacja przez polskiego ustawodawcę analizowanej instytucji uzasadniona była z dwóch powodów. Pierwszy stanowiła oczywista konieczność unifikacji prawa

8 Ibidem.

9 J. Litwin, Prawo o aktach stanu cywilnego. Komentarz, Warszawa 1949, s. 105.

${ }^{10}$ Ibidem.

${ }^{11}$ M. Kolbuszewski, A. Myszkowski, Ustawa o uznaniu zaginionego za zmarlego w opracowaniu teoretycznym i praktycznym, Kraków 1946, s. 72; orzeczenie SN z dnia 20 marca 1957 r., I CR 119/57, OSN 1958, nr 1, poz. 27.

${ }_{12}$ A. Zylber, Unifikacja przepisów..., s. 44.

${ }_{13}$ M. Pazdan, Uznanie za zmarlego i stwierdzenie zgonu w polskim prawie prywatnym międzynarodowym „Studia Iuridica Silesiana”, t. 3, Katowice 1978, s. 68.

14 J. Górski, Wstęp do nauki prawa cywilnego, Poznań 1947, s. 29.

15 I. Różański, Prawo osobowe. Postępowanie o ubezwłasnowolnienie. Postępowanie o uznanie za zmarłego i stwierdzenie zgonu. Komentarz, Kraków 1946, s. 55; F. Zoll, Prawo cywilne w zarysie. Czesść ogólna, Kraków 1948, s. 103. 
cywilnego, drugi - specyficzna sytuacja wynikająca z zakończenia wojny ${ }^{16}$. Sądowe stwierdzenie zgonu miało zatem szczególne znaczenie tuż po zakończeniu II wojny światowej, kiedy ustalenie i zarejestrowanie zgonów milionów obywateli stanowiło poważny problem społeczny. Zarówno interes poszczególnych jednostek, jak i interes społeczny przemawiały za szybkim wprowadzeniem jednolitych przepisów $\mathrm{w}$ tej materii ${ }^{17}$. Zunifikowane i zreformowane przepisy dotyczące postępowania o stwierdzenie zgonu weszły w życie 1 stycznia 1946 r. ${ }^{18}$ Po zakończeniu II wojny światowej sprawy o stwierdzenie zgonu zostały przydzielone do postępowania niespornego, jako sprawy z zakresu prawa osobowego ${ }^{19}$. Zostało to dokonane dekretem $\mathrm{z}$ dnia 18 lipca $1945 \mathrm{r}$. Kodeks postępowania niespornego ${ }^{20}$ oraz dekretem z dnia 29 sierpnia $1945 \mathrm{r}$. w sprawie postępowania o uznanie za zmarłego i stwierdzenie zgonu $^{21}$. Sprawy o stwierdzenie zgonu należały do typowych postępowań niespornych, które zasadniczo cechowały się brakiem sporu o prawo. Wynikały bowiem nie ze sporu o prawo, lecz z potrzeby sądowego ustalenia faktów mających istotne znaczenie prawne. Postępowanie o stwierdzenie zgonu nie miało dwustronnego charakteru, a wydawane w nim orzeczenia wpływały na prawa i obowiązki jego uczestników tylko pośrednio, tj. w takim zakresie, w jakim stanowiły przesłankę unormowania stosunków prawnych, np. spadkowych ${ }^{22}$. Należy zwrócić uwagę, że ustawodawca w rozdziale drugim dekretu w sprawie postępowania o uznanie za zmarłego i stwierdzenie zgonu nie wprowadził zmian w stosunku do przesłanek stwierdzenia zgonu, stanowiąc tym samym w art. 10, iż „do stwierdzenia zgonu

${ }^{16}$ M. Kolbuszewski, A. Myszkowski, Ustawa o uznaniu zaginionego..., s. 72.

17 Orzeczenie SN z dnia 9 lipca 1947 r., C III 756/47; orzeczenie SN z dnia 9 lipca 1947 r., C III 757/47, OSN 1948, nr 1, poz. 2; orzeczenie SN z dnia 5 sierpnia 1947 r., C II 858/47, PN 1848, nr 2-3, s. 209; orzeczenie SN z dnia 21 listopada 1947 r., C I 1399/47, PN 1948, nr 9-10, s. 428; orzeczenie SN z dnia 7 lutego 1948 r., C I 2317/47, OSN 1949, nr 1, poz. 13; orzeczenie SN z dnia 17 grudnia 1949 r., WaC. 16/49, DPP 1950, nr 5, s. 55.

18 Z. Fenichel, Próba charakterystyki ustawodawstwa polskiego za okres 1944-1946, „Demokratyczny Przegląd Prawniczy” 1947, nr 1-2, s. 78; I. Różański, Prawo osobowe..., s. 68.

19 J. Litauer, Kodeks postępowania niespornego. Księga I, Łódź 1946, s. 8; E. Till, Prawo prywatne austriackie, t. I: Nauki ogólne, Lwów 1892, s. 152; A. Laniewski, Patent niesporny. Rozporzadzenie cesarskie o ubezwłasnowolnieniu. Ustawy o uznaniu za zmarłego i dowodzeniu śmierci. Rozporządzenie cesarskie o amortyzacji dokumentów wraz z orzecznictwem bytych sądów austriackich $i$ sądów polskich z dodatkowymi ustawami i rozporządzeniami polskimi oraz okólnikami ministerialnymi, Lwów 1927, s. 226 i n.; K. Konic, Prawo osobowe. Wykład prawnoporównawczy prawodawstw obowiazujacych $w$ Polsce $w$ zestawieniu z kodeksem szwajcarskim, cz. 1, Warszawa 1924, s. 51; M. Haworka, Krótki zarys prawa cywilnego obowiąującego na ziemiach zachodnich Rzeczypospolitej, Poznań 1938, s. 12.

${ }^{20}$ Dekret z dnia 18 lipca 1945 r. Kodeks postępowania niespornego, Dz. U. nr 27, poz. 169.

${ }^{21}$ Dekret z dnia 29 sierpnia 1945 r. w sprawie postępowania o uznanie za zmarłego i stwierdzenie zgonu, Dz. U. poz. 226.

${ }^{22}$ K. Lubiński, Uwagi o terminie „postępowanie nieprocesowe, „Państwo i Prawo” 1986, z. 2, s. $81-83$. 
osoby, której śmierć mimo niesporządzenia aktu zejścia była niewątpliwa, stosować należy odpowiednio przepisy rozdziału pierwszego". Wobec tego aktualność zachowało również orzecznictwo Sądu Najwyższego oraz wypowiedzi doktryny formułowane na gruncie poprzednio obowiązujących przepisów. Jak już wspomniano, sądowe stwierdzenie zgonu miało pozwolić na sporządzenie aktu zgonu w przypadkach, gdy było to niemożliwe w normalnym trybie. Ze względu na tę funkcję zbyteczna była rozbudowana regulacja materialno-prawnych przesłanek tej instytucji. Kierując się pilną potrzebą unormowania niniejszych spraw, przedstawiciele doktryny sugerowali ,szerokie stosowanie instytucji stwierdzenia zgonu, urzeczywistnianej w prostszym i szybszym postępowaniu niż uznanie za zmarłego". Postulowano ,liberalną wykładnię wymogu niewątpliwej śmierci” i podkreślano, że „byłoby rzeczą wskazaną, aby sądy przy wykładni słów ustawy [...] nie postępowały zbyt rygorystycznie, lecz uwzględniały całokształt okoliczności towarzyszących konkretnym faktom, często powszechnie znanym"23. Postanowienie o stwierdzeniu zgonu powodowało zakończenie zdolności prawnej osoby, której dotyczyło postępowanie, co nadawało szczególną wagę temu, by unormowanie postępowania, w którym było ono wydawane, ułatwiało rozpoznanie sprawy, a jednocześnie zapewniało ochronę praw podmiotów zainteresowanych wynikiem postępowania ${ }^{24}$. Ze względu na specyfikę stanów faktycznych leżących u podstaw spraw o stwierdzenie zgonu oraz zapewnienie prawidłowości ich rozstrzygnięć ograniczono zasadę stabilności prawomocnych orzeczeń co do istoty sprawy ${ }^{25}$. Należy także odnotować, że problematyka postępowania o stwierdzenie zgonu znalazła odzwierciedlenie w orzecznictwie Sądu Najwyższego, które ze względu na autorytet najwyższego organu sądowego miało doniosłe znaczenie dla praktyki, jak również dla całego postępowania.

\section{ZARYS PROCEDURY W SPRAWACH O STWIERDZENIE ZGONU}

Jak wspomniano, dla zastosowania instytucji stwierdzenia zgonu musiały zostać spełnione dwie przesłanki. Pierwszą z nich była niewątpliwość śmierci danej osoby, drugą - niesporządzenie aktu zgonu w trybie administracyjnym. Po II wojnie światowej właściwy do orzekania w niniejszych sprawach był sąd grodzki. W sprawach o stwierdzenie zgonu właściwy był sąd, w którego okręgu zmarły miał ostatnie

${ }^{23}$ A. Wolter, Postepowanie w sprawie..., s. 26.

${ }^{24}$ E. Till, Prawo prywatne austriackie, s. 152; A. Laniewski, Patent niesporny..., s. 226; K. Konic, Prawo osobowe..., s. 51; M. Haworka, Krótki zarys prawa cywilnego..., s. 12.

${ }^{25}$ K. Lubiński, Prawomocność materialna orzeczeń w postępowaniu nieprocesowym, „Państwo i Prawo" 2003, z. 11, s. 55. 
miejsce zamieszkania. Jeżeli natomiast nie można było ustalić miejsca zamieszkania i pobytu osoby, której śmierć podlegała stwierdzeniu, wyjątkowo właściwy był sąd dla m. st. Warszawy ${ }^{26}$. Należy mieć również na uwadze stanowisko Sądu Najwyższego, który wyraził pogląd, iż w postępowaniu niespornym kwestię właściwości rzeczowej i miejscowej sądu brano z urzędu pod rozwagę w każdym stanie sprawy ${ }^{27}$. Zasadą było, że sąd wszczynał postępowanie o stwierdzenie zgonu na wniosek osoby zainteresowanej ${ }^{28}$. Na podstawie art. $13 \S 1$ Kodeksu postępowania niespornego uprawnionym do złożenia wniosku w sprawach o stwierdzenie zgonu był każdy, którego praw dotyczył wynik tego postępowania. Do zgłoszenia wniosku o stwierdzenie zgonu uprawniony był zatem każdy zainteresowany, którego praw majątkowych lub niemajątkowych dotyczył wynik postępowania. W każdym wypadku ocena uprawnienia wnioskodawcy do żądania wszczęcia postępowania musiała być dokonywana przez sąd na tle okoliczności konkretnej sprawy. Interes prawny, który stanowił kategorię obiektywną, był integralną częścią omawianego postępowania, uzasadniającą złożenie wniosku o stwierdzenie zgonu ${ }^{29}$. Stanowił on także merytoryczną przesłankę skuteczności wniosku, a brak uprawnienia wnioskodawcy prowadził do jego oddalenia ${ }^{30}$. Warto podkreślić, że zgodnie ze stanowiskiem Sądu Najwyższego z uwagi na znaczenie elementu zaangażowania emocjonalnego w sprawach o stwierdzenie zgonu członkowie rodziny zmarłego, niezależnie od łączącego ich pokrewieństwa czy powinowactwa, uprawnieni byli do zgłoszenia wniosku bez konieczności wykazywania doraźnego interesu prawnego ${ }^{31}$. W postępowaniu o stwierdzenie zgonu sąd prowadził postępowanie dowodowe. Istotą postępowania dowodowego w sprawach o stwierdzenie zgonu było wykazanie istnienia wszystkich okoliczności pozwalających na wydanie orzeczenia uwzględniającego wniosek $^{32}$. Wydanie orzeczenia przez sąd wiązało się z obowiązkiem sporządzenia jego uzasadnienia ${ }^{33}$. Regułą było, że sąd ogłaszał postanowienie na tym samym posiedzeniu, na którym zostało ono wydane. Bezpośrednim skutkiem wydania przez sąd orzeczenia było stwierdzenie, że zaginiony zmarł, a śmierć nastąpiła w chwili oznaczonej w postanowieniu sądu ${ }^{34}$.

${ }^{26}$ A. Bartoszewicz, Postępowanie o uznanie za zmarłego i stwierdzenie zgonu, Warszawa 2007, s. 91.

${ }^{27}$ Orzeczenie SN z dnia 19 października 1949 r., WaC. 4/49, Zb. O. 1/51/3, DPP 7/50/55.

28 A. Jakubecki (red.), Kodeks postępowania cywilnego. Komentarz, Warszawa 2004, s. 759.

${ }^{29}$ Orzeczenie SN z dnia 13 lutego 1953 r., C. 3132/52, OSN 1/54/15.

${ }^{30}$ Orzeczenie SN z dnia 21 października 1948r., PoC. 276/48, PN 1949, nr 3-4, s. 31.

${ }^{31}$ Orzeczenie SN z dnia 6 czerwca 1950 r., Kr. C 212/50, PN 1950, nr 11-12, s. 508.

${ }^{32}$ M. Iżykowski, Charakterystyka prawa uprawdopodobnienia $w$ postępowaniu cywilnym, „Nowe Prawo” 1980, nr 3, s. 71.

33 A. Czerwiński, Uzasadnienie orzeczenia w procesie cywilnym, „Gazeta Sądowa Warszawska" 1934, nr 16, s. 241-242; L. Peiper, Komentarz do Kodeksu postępowania cywilnego, część pierwsza, Kraków 1934, s. 736.

${ }^{34}$ W. Miszewski, Proces cywilny w zarysie, część pierwsza, Warszawa - Łódź 1946, s. 200-201. 
Zgodnie z art. art. $13 \S 1$ dekretu w sprawie postępowania o uznanie za zmarłego i stwierdzenie zgonu w postanowieniu stwierdzającym zgon chwila śmierci powinna była być ściśle oznaczona, stosownie do wyników postępowania ${ }^{35}$. Według Sądu Najwyższego w postanowieniu stwierdzającym zgon chwilę śmierci należało oznaczyć przez podanie takich danych, jakie przewidywało prawo o aktach stanu cywilnego ${ }^{36}$ (art. 55 ust. 1 pkt 2), trzeba więc było bezwzględnie podać nie tylko dzień, miesiąc i rok, ale także godzinę śmierci. W wypadkach, gdy ustalenie godziny było niemożliwe, należało - stosując analogicznie przepis art. 25 pr.a.s.c. - stwierdzić zgon o godz. $24^{37}$, czyli przyjąć koniec dnia jako chwilę śmierci ${ }^{38}$. Sąd Najwyższy wyraził pogląd, iż brak oznaczenia daty śmierci stanowił istotne naruszenie, działające nie tylko przeciwko interesowi osób zainteresowanych, ale także państwa ludowego, zniekształcał bowiem rzeczywistość historyczną. Państwo ludowe było zainteresowane tym, by dokumenty dotyczące ofiar bezprzykładnego terroru hitlerowskiego okupanta były zgodne z rzeczywistością ${ }^{39}$. Pominięcie oznaczenia daty śmierci w sentencji postanowienia o uznaniu za zmarłego było niedopuszczalne i mogło doprowadzić do wielu komplikacji ${ }^{40}$. Zgodnie z art. 88 $\S 2$ pr.a.s.c. prawomocne postanowienie sądu ustalające śmierć osoby zaginionej miało moc aktu zejścia ${ }^{41}$. W istocie sądowe postanowienie o stwierdzeniu zgonu zastępowało dowód śmierci, było więc substytutem nieistniejącego aktu zgonu, który świadczył o rzeczywistej śmierci danej osoby ${ }^{42}$.

\section{ANALIZA WYNIKÓW BADAŃ AKT SĄDOWYCH}

Przedmiotem prowadzonych rozważań i badań są akta spraw o stwierdzenie zgonu, które toczyły się przed Sądem Grodzkim w Krakowie w latach 1946-1950. Jak już wspomniano, spraw o stwierdzenie zgonu było wówczas ponad 5 tysięcy. Dobór akt sądowych miał charakter celowy. Pod uwagę wzięto te sprawy, które zawierały informacje pozwalające uzyskać materiał oddający skalę problemu. $\mathrm{Z}$ uwagi na dużą liczbę akt w pracy przytoczono te, które najdokładniej określają miejsce i okoliczności śmierci ofiar II wojny światowej i najmocniej odzwiercie-

\footnotetext{
${ }^{35}$ A. Bądkowski, Sąd w obliczu..., s. 12.

${ }^{36}$ Dekret z dnia 25 września 1945 r. Prawo o aktach stanu cywilnego, Dz. U. 1945, Nr 48, poz. 272 [dalej: pr.a.s.c.].

${ }^{37}$ Orzeczenie SN z dnia 25 lutego 1948 r., ToC 27/47, PN 9-10/48/298.

${ }_{38}$ Ibidem; orzeczenie SN z dnia 22 lutego 1949 r., WaC. 280/48, PN 11-12/49/511.

${ }^{39}$ Orzeczenie SN z dnia 21 lutego 1953 r., C 2948/52, 1953/2/122.

${ }^{40}$ Orzeczenie SN z dnia 25 lutego 1948 r., ToC. 27/47, PN 9-10/48/298.

${ }^{41}$ J. Litwin, Prawo o aktach..., s. 105.

${ }^{42}$ F. Zoll, Prawo cywilne. Opracowanie głównie na podstawie przepisów obowiąujących w Małopolsce, t. I: Część ogólna, Poznań 1931, s. 141.
} 
dlają jej okrucieństwa. Akta spraw o stwierdzenie zgonu liczyły średnio dziesięć kart. W omawianej spuściźnie sądowej można znaleźć niewielką liczbę szczególnie interesujących akt, w których znajduje się oryginalna korespondencja wysyłana przez więźniów z obozów koncentracyjnych lub wzmianki o listach czy kartkach wysyłanych przez osadzonych. Niektóre akta zawierają oryginalne dokumenty, takie jak: metryki urodzin, ślubu, a niekiedy także świadectwa przynależności religijnej. Szczególnie dużą wartość badawczą mają dokumenty urzędowe, takie jak: poświadczenia Polskiego Czerwonego Krzyża, zaświadczenia miejskich urzędów obwodowych, zarządów miejskich czy urzędowe depesze. Po zakończeniu II wojny światowej sądy grodzkie, rozpatrując sprawy o uznanie za zmarłego, oznaczały je sygnaturą „Zg”. Wszystkie zachowane akta przechowywane są w Archiwum Narodowym w Krakowie, przy ulicy Grodzkiej 52.

\subsection{Narodowość osób, wobec których toczyło się postępowanie o stwierdzenie zgonu}

Pierwszym zadaniem badawczym było ustalenie na podstawie analizy tysiąca akt sądowych narodowości osób, w stosunku do których Sąd Grodzki w Krakowie wydał postanowienie o stwierdzeniu zgonu. Wyniki badań obrazuje tabela 1 .

Tabela 1. Narodowość osób, wobec których toczyło się postępowanie o stwierdzenie zgonu

\begin{tabular}{|l|c|c|}
\hline \multirow{2}{*}{ Narodowość osób } & \multicolumn{2}{|c|}{ Akta } \\
\cline { 2 - 3 } & $\mathrm{N}$ & $\%$ \\
\hline Żydzi & 789 & 78,9 \\
Polacy & 211 & 21,1 \\
\hline Razem & 1000 & 100,0 \\
\hline
\end{tabular}

Źródło: opracowanie własne.

Przedstawione dane wskazują, że w większości spraw (78,9\%) postępowanie o stwierdzenie zgonu dotyczyło obywateli polskich pochodzenia żydowskiego. Przykładem może być sprawa I Zg 8/46, w której wnioskodawczyni S.E. - żona zaginionego K. E.- rewidenta Dyrekcji Państwowych Kolei w Krakowie, zeznała, że z powodu żydowskiego pochodzenia jej mąż podczas okupacji niemieckiej został zmuszony do opuszczenia Krakowa. Przeniósł się w okolice Zabierowa, gdzie zamieszkał w Dolinie Będkowickiej w willi inż. L.R., w której przebywało jeszcze kilka osób pochodzenia żydowskiego. W dniu 5 lipca 1942 r. gestapo aresztowało dziewięć osób, które tam przebywały, w tym jej męża E.K. Przewieziono ich do aresztu Sądu Grodzkiego w Krzeszowicach, skąd następnie wszystkich przetransportowano do Skawiny, gdzie ulokowano ich na łące w pobliżu stacji kolejowej, razem z inną grupą osób, w liczbie około stu. Następnie przetransportowano ich na 
teren pobliskiej gromady Kostrze, gdzie nad ranem 9 lipca 1942 r. wszystkich rozstrzelano, a ciała zamordowanych zakopano w trzech dołach. Na podstawie zeznań wnioskodawczyni i zaświadczenia Krakowskiego Starostwa Powiatowego z dnia 13 kwietnia 1946 r., stwierdzono, że odbyła się ekshumacja zwłok zamordowanego, które zostały rozpoznane, a następnie przewiezione na Cmentarz Rakowicki ${ }^{43}$.

Jak wynika z historii, co potwierdzają także archiwalia Sądu Grodzkiego w Krakowie, wybuch II wojny światowej był najtragiczniejszym okresem w dziejach narodu żydowskiego, podczas którego w niemal całej Europie, a szczególnie w okupowanej Polsce, naziści przystąpili do „ostatecznego rozwiązania kwestii żydowskiej”44, gdyż Hitler uznał ich za „podludzi”"45. Generalne Gubernatorstwo ${ }^{46}$ stało się wraz z siecią gett, obozów pracy przymusowej, obozów koncentracyjnych i obozów śmierci centrum zagłady milionów Żydów z Polski i innych krajów podbitych przez Niemców. Polityka okupanta wobec polskich Żydów została zawarta w dekrecie Centralnego Urzędu Bezpieczeństwa Rzeszy z 21 września 1939 r. Określał on wytyczne postępowania wobec ludności żydowskiej na zajętych przez wojska hitlerowskie terenach. Przewidywał m.in. izolację Żydów, usunięcie ich z życia gospodarczego, gromadzenie ich w gettach, pracę przymusową. Niemcy dążyli bowiem do wymordowania całego narodu żydowskiego ${ }^{47}$. Żydzi żyli w ciągłym strachu przed łapankami, obozami koncentracyjnymi, aresztowaniami, wywózką ,na roboty”. Niewielki odsetek z nich miał szansę przeżyć dzięki „dobrym Niemcom". Badania pokazały, że Żydzi poddawani byli różnym represjom ze strony niemieckich okupantów ${ }^{48}$. Wielu z nich wysłano do obozów śmierci, przede wszystkim do obozu zagłady w Bełżcu, skąd większość już nie wróciła.

W Sądzie Grodzkim w Krakowie rozpatrywana była sprawa I Zg 32/46 o stwierdzenie zgonu członków czteroosobowej rodziny. Wszyscy ujęci we wniosku

${ }^{43}$ Postanowienie Sądu Grodzkiego w Krakowie z dnia 7 lutego 1946 r., sygn. I Zg 8/46.

${ }^{44}$ Rozkaz H. Göringa do szefa Głównego Urzędu Bezpieczeństwa Rzeszy R. Heydricha, nakazujący mu opracowanie generalnego planu „rozwiązania kwestii żydowskiej w Europie”, 31 VII 1941 r. [w:] Eksterminacja Żydów na ziemiach polskich w okresie okupacji hitlerowskiej. Zbiór dokumentów, oprac. T. Berenstein, A. Eisenbach, A. Rukowski, Warszawa 1957, s. 261.

45 J. Grabowski, Ratowanie Żydów za pieniadze: przemyst pomocy, „Zagłada Żydów. Studia i Materiały" 2008, nr 4, s. 82-83; J. Tokarska-Bakir, Sprawiedliwi niesprawiedliwi, niesprawiedliwi sprawiedliwi, „Zagłada Żydów. Studia i Materiały” 2008, nr 4, s. 170-214.

${ }^{46}$ Powstałe w październiku 1939 r. z okupowanych polskich terenów niewcielonych do Rzeszy Niemieckiej obejmowało swoim zasięgiem pięć dystryktów: lubelski, lwowski, krakowski, warszawski i radomski.

${ }^{47}$ J. Grabowski, Ratowanie Żydów..., s. 82-83; J. Tokarska-Bakir, Sprawiedliwi niesprawiedliwi..., s. 170-214.

${ }^{48}$ Fakty niezbicie dowodzą, że zbrodniczy rząd niemiecki przystąpił do wykonania zapowiedzi Hitlera, że ,5 minut przed końcem wojny, jakkolwiek ona się zakończy, wymorduje on wszystkich Żydów w Europie". Zob. W Bartoszewski, Z. Lewinówna, Ten jest z ojczyzny mojej. Polacy z pomoca Żydom1939-1945, Kraków 1969, s. 961-963. 
zostali w maju 1942 r. podczas akcji przeciw ludności żydowskiej wywiezieni do Bełżca i już nie wrócili. Do akt sprawy dołączone zostało poświadczenie Wojewódzkiej Żydowskiej Komisji Historycznej w Krakowie, w której czytamy: „Fakt wywiezienia do obozu w Bełżcu jest ponad wszelką wątpliwość równoznaczny z faktem śmierci wywiezionych"49. Natomiast z akt sprawy I Zg 850/46 wynika, że wnioskodawczyni M.G. po wkroczeniu wojsk niemieckich do Polski wyjechała z Krakowa na czasowy pobyt do rodziny w Gdowie. W dniu 22 sierpnia 1942 r. w czasie akcji wysiedleńczej Żydów została wywieziona przez okupantów do Wieliczki, a stamtąd w zbiorowych transportach Żydów do obozu w Bełżcu. W aktach sprawy czytamy, że „M.G. w sierpniu 1942 r. ponad wszelką wątpliwość została stracona" ${ }^{50}$. Obozy stały się miejscem masowej eksterminacji, która w efekcie miała doprowadzić do unicestwienia całych grup ludności. Jeszcze przed sformułowaniem idei „ostatecznego rozwiązania” funkcjonowało pojęcie „wyniszczenia przez pracę". Osoby chore, starsze czy niezdolne do pracy skazywano na śmierć. Wyniki badań wskazują, że Niemcy przeprowadzali akcję dzielenia ludności żydowskiej na „pracującą” i „niepracującą”. Obrazuje to sprawa I Zg 291/46, w której W.H. od 25 września 1941 r. do 1 czerwca 1942 r. mieszkał w getcie krakowskim, przy ul. Limanowskiego 16 m. 6. W dniach 29 i 30 maja 1942 r. Niemcy zarządzili rejestrację wszystkich przebywających w getcie, z tym, że ci Żydzi, którzy na kartach otrzymali odpowiednią pieczęć, stwierdzającą ich zdolność do pracy, byli uprawnieni do dalszego pobytu w getcie. W.H. takiej pieczęci jednak nie otrzymał. W dniu 1 czerwca 1942 r. policja niemiecka przystąpiła do akcji wysiedleńczej i o godz. 16 W.H. został zaprowadzony na stację kolejową Prokocim. Tam stłoczono wszystkich wysiedlonych Żydów w wagonach towarowych, wagony zaplombowano, po czym cały transport skierowano do obozu śmierci w Bełżcu, gdzie wszyscy zostali straceni przez otrucie gazem ${ }^{51}$.

\subsection{Pleć osób, wobec których toczylo się postępowanie o stwierdzenie zgonu}

Z przeprowadzonych badań wynika, że Sąd Grodzki w Krakowie wydał postanowienie o stwierdzeniu zgonu 791 mężczyzn i 209 kobiet. Wyniki badań obrazuje tabela 2. W większości spraw postępowanie o stwierdzenie śmierci dotyczyło mężczyzn (79\%). Tak było np. w sprawie I Zg 305/46, w której M.B., zamieszkała w Krakowie, złożyła wniosek o stwierdzenie zgonu swojego męża A.B. Wspomniany A.B. 3 września 1939 r. został zmobilizowany i wyjechał z Krakowa do Brześcia nad Bugiem do 33. pułku artylerii lekkiej. W czasie wojny A.B. został

\footnotetext{
49 Postanowienie Sądu Grodzkiego w Krakowie z dnia 28 lutego 1946 r., sygn. I Zg 8/46.

${ }^{50}$ Postanowienie Sądu Grodzkiego w Krakowie z dnia 15 września 1946 r., sygn. I Zg 850/46.

${ }^{51}$ Postanowienie Sądu Grodzkiego w Krakowie z dnia 5 czerwca 1946 r., sygn. I Zg 291/46.
} 
Tabela2. Płeć osób, wobec których toczyło się postępowanie o stwierdzenie zgonu

\begin{tabular}{|l|r|r|}
\hline \multirow{2}{*}{ Narodowość osób } & \multicolumn{2}{|c|}{ Akta } \\
\cline { 2 - 3 } & 791 & $\%$ \\
\hline Mężczyźni & 209 & 79,1 \\
Kobiety & 1000 & 21,1 \\
\hline Razem & & 100,0 \\
\hline
\end{tabular}

Źródło: opracowanie własne.

internowany przez władze rosyjskie i umieszczony w obozie w Kozielsku. Dowodem tego był list z dnia 29 listopada 1939 r. i kartka z dnia 20 stycznia 1940 r. Latem $1941 \mathrm{r}$. oficerowie polscy internowani w tym obozie zostali wywiezieni do Katynia i rozstrzelani, a wśród nich wymieniony A.B. ${ }^{52}$

Zebrany materiał badawczy wskazuje, że Sąd Grodzki w Krakowie stwierdził zgon 209 kobiet. Przed sądem tym rozpatrywana była np. sprawa o sygn. I Zg 114/46, w której wnioskodawca L.H., zamieszkały w Krakowie, wniósł o stwierdzenie zgonu swojej żony F. H., urodzonej w Brnie 15 grudnia 1914 r. Wspólnie z wnioskodawcą mieszkała ona w Krakowie. Według zeznań wnioskodawcy wyżej wspomniana miała zginąć z końcem stycznia 1945 r. w Prusach Wschodnich. Świadkiem w sprawie była B.K., zamieszkała w Krakowie, która zeznała, że F.H. zginęła śmiercią tragiczną w miejscowości Palemniken w Prusach Wschodnich. Niemcy wyprowadzili transport pięciu tysięcy kobiet w morze i strzelali do nich z karabinów maszynowych. Wszystkie kobiety zginęły, a wśród nich była wspomniana F.H., zaś ciała zabitych kobiet wpadły do morza ${ }^{53}$.

\subsection{Charakterystyka wnioskodawcy}

Przeprowadzone badania dostarczyły informacji na temat osoby wnioskodawcy, co obrazuje tabela 3. Z przedstawionych w niej danych wynika, że wniosek o stwierdzenie zgonu najczęściej składał współmałżonek (51,1\%). Przykładowo tak było w sprawie I Zg 35/46, w której J.B., urodzona w Krakowie 9 marca 1912 r., wraz z mężem dr. S.B., który był wnioskodawcą, mieszkała na stałe przed wojną w Krakowie. W dniu 16 listopada została aresztowana i przewieziona do obozu koncentracyjnego w Płaszowie, gdzie 27 listopada 1943 r. wyznaczono pięćdziesiąt osób na rozstrzelanie, wśród których znalazła się żona wnioskodawcy ${ }^{54}$.

W 26 sprawach wniosek o stwierdzenie zgonu został złożony przez zstępnych. Tak było np. w sprawie I Zg 92/46, w której wnioskodawczyni A.B., studentka

\footnotetext{
${ }^{52}$ Postanowienie Sądu Grodzkiego w Krakowie z dnia 10 maja 1946 r., sygn. I Zg 305/46.

53 Postanowienie Sądu Grodzkiego w Krakowie z dnia 19 lutego 1946 r., sygn. I Zg 114/46.

${ }^{54}$ Postanowienie Sądu Grodzkiego w Krakowie z dnia 4 lutego 1946 r., sygn. I Zg 35/46.
} 
Tabela 3. Osoba składająca wniosek w sprawach o stwierdzenie zgonu

\begin{tabular}{|l|r|r|}
\hline \multirow{2}{*}{ Osoba składająca wniosek } & \multicolumn{2}{|c|}{ Akta } \\
\cline { 2 - 3 } & $\mathrm{N}$ & $\%$ \\
\hline Małżonek & 519 & 51,9 \\
Zstępni & 267 & 26,7 \\
Krewni & 89 & 8,9 \\
Rodzeństwo & 76 & 7,6 \\
Powinowaci & 32 & 3,2 \\
Wstępni & 17 & 1,7 \\
\hline Razem & 1000 & 100,0 \\
\hline
\end{tabular}

Źródło: opracowanie własne.

Uniwersytetu Jagiellońskiego w Krakowie, złożyła wniosek o stwierdzenie zgonu swojego ojca M.B., urodzonego 18 października 1888 r. w Skale nad Zbruczem, oraz swojej matki B.B., urodzonej 6 lipca 1890 r. w Burdjakówce nad Zbruczem. Rodzice wnioskodawczyni stracili życie 10 listopada 1942 r. w czasie transportu z Brzeska Nowego, gdzie wówczas mieszkali i skąd zostali wysiedleni do Miechowa. Zostali oni zastrzeleni przez eskortującą ten transport policję ${ }^{55}$.

W 89 przypadkach wniosek składany był przez krewnych. I tak z akt w sprawy I Zg 61/46 wynika, że R.W., zamieszkała w Krakowie, wniosła o stwierdzenie zgonu swoich ciotek: T.G., liczącej lat 38, i R.G., liczącej lat 44. Ciotki wnioskodawczyni mieszkały przed wojną i w czasie okupacji w Krakowie. W marcu 1943 r. obie trafiły do obozu koncentracyjnego dla Żydów w Płaszowie i tam podczas jednej $\mathrm{z}$ akcji zostały wybrane i zastrzelone przez Niemców dnia 25 maja $1943 \mathrm{r}^{56}$

W 76 sprawach wniosek składany był przez rodzeństwo zaginionych. I tak np. w sprawie I Zg 249/46, w której wnioskodawca A.G., brat zaginionych, zamieszkały w Przemyślu, złożył wniosek celem stwierdzenia zgonu R.I. oraz C.I. Zaginieni mieli przed wybuchem wojny stałe miejsce zamieszkania w Krakowie. W 1942 r. w okresie przeprowadzanych przez okupanta niemieckiego pogromów ludności żydowskiej w postaci „akcji przesiedleniowej” oboje zostali wywiezieni do Bełżca i tam rozstrzelani ${ }^{57}$.

W 32 przypadkach wnioskodawcą byli powinowaci. Za przykład może posłużyć sprawa o sygn. Zg 51/46, w której I.G., zamieszkały w Krakowie, wniósł o stwierdzenie zgonu swojego teścia Ch.I., zamieszkałego przed wojną w Krakowie. Wspomniany Ch.I. został przez Niemców wysiedlony z Krakowa i przebywał w Wieliczce. Podczas akcji wysiedleńczej dostał się do getta w Krakowie.

\footnotetext{
55 Postanowienie Sądu Grodzkiego w Krakowie z dnia 5 lutego 1946 r. , sygn. I Zg 92/46.

56 Postanowienie Sądu Grodzkiego w Krakowie z dnia 2 lutego 1946 r., sygn. I Zg 61/46.

57 Postanowienie Sądu Grodzkiego w Krakowie z dnia 17 marca 1946 r., syg. I Zg 249/46.
} 
W czasie pobytu w getcie zachorował i po przebytym tyfusie brzusznym zmarł na udar serca ${ }^{58}$.

W 17 przypadkach wnioskodawcami byli rodzice. Przykładowo w sprawie I Zg 345/46 S.A. domagał się stwierdzenia zgonu swojego syna F.A., urodzonego 27 października 1899 r. w Krakowie. F.A. brał udział w powstaniu warszawskim. Wnioskodawca załączył do wniosku zawiadomienie Zarządu Polskiego Czerwonego Krzyża z dnia 29 listopada 1945 r., które stwierdzało, że wspomniany F.A., pseudonim „Senator”, figuruje w prowadzonej ewidencji strat wojennych ${ }^{59}$.

\subsection{Powody złożenia wniosku}

Osobnym problem badawczym było ustalenie w wyniku analizy tysiąca spraw o stwierdzenie zgonu powodów, dla których składany był wniosek w celu wydania przez Sąd Grodzki w Krakowie postanowienia stwierdzającego zgon danej osoby. Rezultaty badań przedstawia tabela 4 .

Tabela 4. Powody złożenia wniosku

\begin{tabular}{|l|r|r|}
\hline \multirow{2}{*}{\multicolumn{1}{|c|}{ Powody złożenia wniosku }} & \multicolumn{2}{|c|}{ Akta } \\
\cline { 2 - 3 } & $\mathrm{N}$ & $\%$ \\
\hline Wszczęcie postępowania spadkowego & 638 & 63,8 \\
Brak danych & 234 & 23,4 \\
Rozwiązanie małżeństwa & 108 & 10,8 \\
Uzyskanie zaopatrzenia społecznego & 13 & 1,3 \\
Uzyskanie renty wdowiej & 7 & 0,7 \\
\hline Razem & 1000 & 100,0 \\
\hline
\end{tabular}

Źródło: opracowanie własne.

Zebrany w tabeli materiał empiryczny dowodzi, że w 638 sprawach wnioskodawcy przysługiwało ustawowe prawo dziedziczenia po zmarłym i postanowienie sądu stwierdzające śmierć niezbędne było wnioskodawcy w celu przedłożenia sądowi spadkowemu. W 234 sprawach wnioskodawca nie określił, w jakim celu było mu potrzebne postanowienie sądu. Nie mamy zatem dostatecznych informacji, aby stwierdzić, jaki interes prawny przyświecał osobie składającej wniosek. Dalej na podstawie analiz można stwierdzić, że w 108 przypadkach postanowienie o stwierdzające zgon było niezbędne wnioskodawcy do rozwiązania małżeństwa. W kolejnych 13 sprawach wnioskodawca chciał uzyskać zaopatrzenie społeczne, natomiast w 7 przypadkach postanowienie stwierdzające zgon współmałżonka było niezbędne wnioskodawczyni do uzyskania renty wdowiej.

${ }^{58}$ Postanowienie Sądu Grodzkiego w Krakowie z dnia 19 lutego 1946, sygn. Zg 51/46.

${ }^{59}$ Postanowienie Sądu Grodzkiego w Krakowie z dnia 2 kwietnia 1946 r., sygn. I Zg 345/46. 


\subsection{Miejsce i okoliczności śmierci}

Otrzymane wyniki badań i dokonane na ich podstawie analizy dowodzą, że zdecydowana większość osób, wobec których toczyło się postępowanie o stwierdzenie zgonu, poniosła śmierć w wyniku różnych działań prowadzonych przez okupantów w czasie wojny. Zebrany materiał empiryczny dowodzi, że w większości przypadków ludzie byli aresztowani przez władze niemieckie i osadzani w więzieniach, gettach bądź obozach koncentracyjnych. W takich miejscach człowiek był zniewolony przez rzeczywistość obozową i w żaden sposób nie mógł przeciwstawić się powszechnemu okrucieństwu i bezsilności, w każdej chwili był narażony na ogromne niebezpieczeństwo. Przykładowo z akt sprawy I Zg 4/46 wynika, iż rodzice wnioskodawczyni mieszkali aż do wybuchu wojny w Krakowie. Następnie przebywali w getcie w Otwocku. 17 lipca 1942 r. okupant przystąpił do likwidacji tego getta - masowo rozstrzeliwano starsze osoby, a młodszych transportowano do warszawskiego getta. Rodzice wnioskodawczyni zostali na jej oczach rozstrze$\operatorname{lan}^{60}$.W innej w sprawie (I Zg 103/46) I.G. w 1940 r. w związku z wysiedleniem Żydów z Krakowa wyjechała do Warszawy, gdzie zamieszkała w getcie krakowskim. Latem 1942 r. miała miejsce likwidacja tzw. małego getta w Warszawie i wówczas Niemcy część mieszkających w tym getcie Żydów wymordowali, a część wywieźli do Bełżca, gdzie wszyscy zginęli w komorze gazowej ${ }^{61}$.

Wyniki badań dowodzą, że wiele osób straciło także życie podczas akcji antyżydowskich. Tak było np. w sprawie I Zg 39/46, która dotyczyła R.I., urodzonego 8 maja 1883 r. w Gorlicach, oraz jego żony C.I., urodzonej 9 kwietnia 1881 r. w Nawsiu Kołaczyckim koło Jasła. Zarówno R.I., jak i jego żona mieli w Krakowie stałe miejsce zamieszkania. W 1942 r. w czasie przeprowadzonych przez okupantów pogromów ludności żydowskiej w postaci „akcji przesiedleniowych” oboje zostali wywiezieni do Bełżca - miejsca śmierci Żydów, zwożonych z całej Europy, i tam zostali rozstrzelani przez okupanta ${ }^{62}$.

Z badań i opartych na nich analiz wynika, że wiele osób poniosło śmierć w obozach pracy. I tak np. w sprawie I Zg 21/46 S.H., urodzony 7 lutego $1907 \mathrm{r}$. w Brzesku, przed wojną i w czasie wojny, aż do wysiedlenia, mieszkał w Krakowie. W 1942 r. został pozbawiony wolności przez Niemców i przewieziony do obozu pracy w Płaszowie. Dnia 31 listopada 1942 r. na skutek postrzelenia przez załogę obozową SS z rozkazu kierownika obozu zmarł tam i został pochowany ${ }^{63}$. Wnioskodawcą w sprawie był brat zaginionego J.H., zamieszkały w Krakowie.

\footnotetext{
${ }^{60}$ Postanowienie Sądu Grodzkiego w Krakowie z dnia 1 lutego 1946 r., sygn. I Zg 4/46.

${ }^{61}$ Postanowienie Sadu Grodzkiego w Krakowie z dnia 23 lutego 1946 r., sygn. I Zg 103/46.

${ }_{62}$ Postanowienie Sądu Grodzkiego w Krakowie z dnia 12 lutego 1946 r., sygn. I Zg 39/46.

${ }^{63}$ Postanowienie Sądu Grodzkiego w Krakowie z dnia 9 lutego 1946 r., sygn. I Zg 21/46.
} 
Z analizy akt wynika, że ludzie ginęli również przez okrucieństwa okupantów, żołnierzy czy niemieckiej policji. Aby dokładniej przedstawić obraz upadku moralności człowieka, warto przywołać przykład z akt sądowych. Z akt sprawy I Zg 45/46 wynika, że dr J.G., urodzony 8 stycznia 1893 r. w Radwanowicach, który z zawodu był adwokatem, zamieszkały do wybuchu wojny w Krakowie, 2 kwietnia 1941 r. został aresztowany przez gestapo i osadzony w więzieniu w Krakowie przy ulicy Montelupich, a po jakimś czasie przewieziony do obozu koncentracyjnego w Oświęcimiu. Trafił tam do „karnej kompanii”, która była zatrudniona przy wydobywaniu żwiru z głębokiego dołu - żwir był wywożony z dołu taczkami, a następnie nad brzegiem dołu ładowany na wózki. Co jakiś czas niemiecki „Capo”, zawodowy kryminalista, wysyłał upatrzonego więźnia (jednym z nich był J.G.) na wyznaczone miejsce w dole pod pozorem, że ma stamtąd przynieść jakiś przedmiot, a gdy ten był już na dole „Capo” dawał rozkaz innym więźniom, aby wywrócili wyładowany żwirem wózek. Spadająca z kilkudziesięciu metrów masa żwiru zabiła wówczas stojącego na dole J.G. ${ }^{64} \mathrm{Z}$ niezwykłym przypadkiem mamy też do czynienia w sprawie I Zg 295/46, w której E. G., porucznik straży pożarnej, zamieszkały w Krakowie, 11 listopada 1943 r. został aresztowany przez gestapo za pracę podziemną przeciw okupantom niemieckim i osadzony w więzieniu przy ul. Montelupich w Krakowie. Z okazji rocznicy powstania listopadowego 29 listopada 1943 r. E.G. wraz ze współwięźniami zamierzał podnieść bunt i przez unieszkodliwienie jednego ze strażników przy otwieraniu celi więźniowie podczas „kiblowania” chcieli odebranymi kluczami pootwierać sąsiednie cele i zainicjować ucieczkę. Czyn ten jednak się nie udał i wszyscy w liczbie siedemnastu wraz z E.G. zostali zastrzeleni na miejscu ${ }^{65}$.

Analiza danych źródłowych ujawniła, że w jednym wypadku mamy do czynienia ze śmiercią samobójczą. Tak było w sprawie I Zg 232/48, w której dr M.B., adwokat, zamieszkały w Krakowie, wyjechał na początku wojny w 1939 r. do Rzeszowa, a tam w wyniku prześladowania przez Niemców uległ „depresji psychicznej" i rzucił się przez okno na ulicę. Sąd Grodzki w Krakowie na podstawie zeznań świadków ustalił, że M.B. w pierwszych dniach września 1939 r. popełnił samobójstwo, rzucając się z okna na ulicę. Przyjęto zatem dzień 30 września 1939 r. jako dzień jego zgonu ${ }^{66}$.

\subsection{Dowody w postępowaniu o stwierdzenie zgonu}

Dowody w postępowaniu o stwierdzenie zgonu opierały się na ogólnych i właściwych całemu postępowaniu cywilnemu regułach dowodowych. Przepisy

${ }^{64}$ Postanowienie Sądu Grodzkiego w Krakowie z dnia 14 lutego 1946 r., sygn. I Zg 45/46.

${ }^{65}$ Postanowienie Sądu Grodzkiego w Krakowie z dnia 5 kwietnia 1946 r., sygn. I Zg 295/46.

${ }^{66}$ Postanowienie Sądu Grodzkiego w Krakowie z dnia 8 maja 1948 r., sygn. I Zg 232/48. 
dawnego Kodeksu postępowania cywilnego ${ }^{67}$ odnosiły się bowiem do kwestii dowodowych jedynie pośrednio, co sprawiało, że w tym zakresie w postępowaniu o stwierdzenie zgonu zastosowanie znajdowały przepisy ogólne postępowania niespornego. Należy podkreślić, że na sądzie spoczywał obowiązek przeprowadzenia wszystkich dostępnych dowodów, które pozwoliłyby na precyzyjne określenie chwili śmierci zaginionego ${ }^{68}$. W postępowaniu o stwierdzenie zgonu nie przewidziano dowodu obligatoryjnego. Jednym z najczęściej przeprowadzanych dowodów był dowód z przesłuchania wnioskodawcy i zeznań świadków. W postępowaniu niespornym nie było konieczne przesłuchanie w celach dowodowych wszystkich uczestników postępowania; wystarczyło jedynie przesłuchanie tych uczestników, co do których istniało przypuszczenie, że mogą posiadać istotne informacje mające wartość dowodową w sprawie ${ }^{69}$. Warto przywołać kilka przykładów $\mathrm{z}$ akt sądowych, w których dowodem w sprawie były zeznania wnioskodawcy lub/i świadków. W sprawie I Zg 7/46 wnioskodawca F.W., mąż zaginionej M.W., odnalazł świadków Irenę i Stanisława Ś., zamieszkałych w Kielcach, którzy byli naocznymi świadkami śmierci jego żony. Zeznania świadków zostały spisane w urzędzie parafialnym w Kielcach 16 i 22 maja 1945 r., uwierzytelnione pieczęcią tego urzędu oraz podpisem następcy proboszcza, a następnie przedstawione przed Sądem Grodzkim w Krakowie. Na podstawie zeznań świadków ustalono, że M.W. została zabita 23 marca 1944 r., trafiona w głowę odłamkiem pocisku armatniego ${ }^{70}$. W innej sprawie (I Zg 3/46) P.B. został aresztowany przez gestapo 3 września 1944 r. i osadzony najpierw w więzieniu przy ul. Montelupich, a potem przewieziony do obozu koncentracyjnego w Oświęcimiu. Powołany świadek F.M. przebywał razem z nim w oświęcimskim obozie, również jako więzień. Świadek zeznał, że P.B. został zamordowany przez esesmana 8 stycznia 1943 r. Podczas apelu został uderzony przez niego pięścią w żołądek, a następnie powalony na ziemię i przygnieciony butem w szyję - w ten sposób został zabity ${ }^{71}$.W kolejnej sprawie (I Zg 79/46) Sąd Grodzki w Krakowie po rozpoznaniu wniosku S.L., zamieszkałej w Krakowie, o stwierdzenie zgonu G.G. i R.G. na podstawie przeprowadzonych dochodzeń urzędowych i przesłuchania zaprzysiężonych zeznań wnioskodawczyni i świadka M.S. ustalił, że małżeństwo G. zostało 1 lipca 1943 r. rozstrzelane przez niemiecką policję w obozie w Płaszowie, a ich zwłoki wywieziono na nasyp kolejowy ${ }^{72}$. Co do zasady przedmiotem zeznań w postępowaniu o stwierdzenie zgonu powinny

${ }^{67}$ Ustawa z dnia 29 listopada 1930 r., Dz. U. nr 83, poz. 651.

${ }^{68}$ A. Bartoszewicz, Postępowanie o uznanie..., s. 123.

${ }^{69}$ E. Marszałkowska-Krześ, Postępowanie nieprocesowe w sprawach osobowych oraz rodzinnych, Wrocław 2012, s. 61.

${ }^{70}$ Postanowienie Sądu Grodzkiego w Krakowie z dnia 1 lutego 1946 r., sygn. I Zg 7/46.

${ }^{71}$ Postanowienie Sądu Grodzkiego w Krakowie z dnia 1 lutego 1946 r., sygn. I Zg 3/46.

${ }^{72}$ Postanowienie Sądu Grodzkiego w Krakowie z dnia 1 marca 1946 r., sygn. I Zg 79/46. 
były być osobiste i bezpośrednie spostrzeżenia świadków, jednak z uwagi na specyfikę omawianych spraw nie można było z góry odrzucić zeznań „świadków ze słyszenia", relacjonujących bezpośrednie spostrzeżenia innych osób. Aby uwiarygodnić zeznania świadka, sąd musiał uwzględnić wpływ, jaki na zdolność świadka do obiektywnego odtwarzania faktów miały procesy zachodzące w sferze jego przeżyć psychicznych ${ }^{73}$. W omawianym postępowaniu wpływ taki mogło mieć zwłaszcza silne wzburzenie emocjonalne towarzyszące niebezpiecznemu zdarzeniu, bliska więź z osobą, której dotyczyło postępowanie, albo zawodność pamięci, gdy postępowanie toczyło się po upływie znacznego czasu od zaginięcia, lub chwili, w której nastąpił zgon ${ }^{74}$.

W takim postępowaniu często wykorzystywane były także dowody z dokumentu. Szczególnie wiarygodnym środkiem dowodowym, z uwagi na domniemanie zgodności z prawdą, były dokumenty urzędowe. Kluczowym dowodem mogły być tutaj akty stanu cywilnego, stanowiące wyłączny dowód stwierdzonych w nich zdarzeń, a także akty notarialne i inne dokumenty notarialne ${ }^{75}$. Tak było np. w sprawie I Zg 335/46, w której syn wnioskodawczyni J.G. poległ dnia 20 września 1939 r. w okolicy Tomaszowa Lubelskiego. W dniu 23 kwietnia 1940 r. jego zwłoki zostały ekshumowane i pochowane na cmentarzu w Majdanie Wielkim. Na dowód tego wnioskodawczyni załączyła zawiadomienie Polskiego Czerwonego Krzyża z dnia 10 stycznia 1942 r. ${ }^{76} \mathrm{~W}$ innej sprawie (I Zg 108/46) E.D., zamieszkała w Krakowie, wniosła o stwierdzenie zgonu swojej matki H.J. Zmarła ona 19 lutego w Kazachstanie, o czym świadczył dowód śmierci wydany przez kierownika kołchozu z pieczątką urzędową w uwierzytelnionym przekładzie na język polski. Dokument ten przywiózł ze sobą mąż wnioskodawczyni L.D., który był obecny przy jej śmierci ${ }^{77}$.

W archiwaliach Sądu Grodzkiego w Krakowie można także znaleźć jednostkowe akta, w których znajduje się korespondencja władz obozowych - najczęściej zawiadomienia o śmierci osadzonego w obozie. Wśród analizowanych akt sądowych jest sprawa I Zg 39/50, z której dowiadujemy się, że J.S. został w grudniu 1941 r. zabrany z mieszkania w Krakowie przez komendanta policji i przewieziony do więzienia Sądu Okręgowego w Krakowie, a stamtąd do obozu koncentracyjnego w Oświęcimiu, skąd do lutego 1942 r. wysyłał listy do swojej żony. W jednym z nich

${ }^{73}$ K. Knoppek, Niezdolność do spostrzegania lub przekazywania spostrzeżeń jako okoliczność wyłączająca świadka od składania zeznań w postępowaniu cywilnym, „Nowe Prawo” 1982, nr 1-2, s. 89; M. Płachta, Kryteria oceny wiarygodności zeznań świadków w praktyce sąowej, „Studia Prawnicze" 1984, nr 1-2, s. 79; J.M. Staniak, Badania nad psychologicznymi uwarunkowaniami wiarygodności zeznań świadków [w:] S. Waltoś (red.), Świadek w procesie sąowym, Warszawa 1985, s. 396.

${ }^{74}$ A. Bartoszewicz, Postępowanie o uznanie..., s. 146.

75 L. Morawski, Domniemania a dowody prawnicze, Toruń 1981, s. 71.

76 Postanowienie Sądu Grodzkiego w Krakowie z dnia 11 maja 1946 r., sygn. I Zg 335/46.

77 Postanowienie Sądu Grodzkiego w Krakowie z dnia 15 marca 1946 r., sygn. I Zg 108/46. 
pisał, że ,jest traktowany po ludzku”. W odpowiedzi na ostatni list jego żona otrzymała odpowiedź, iż J.S. przebywał w obozie koncentracyjnym w Oświęcimiu jako więzień nr 25479, gdzie zmarł 22 marca $1942 \mathrm{r}^{78} \mathrm{~W}$ Sądzie Grodzkim w Krakowie rozpatrywana była również sprawa z wniosku H.G. o stwierdzenie zgonu J.G., który jako major WP w 1940 r. walczył na froncie francuskim, po czym dostał się do niewoli niemieckiej i od tego czasu ślad po nim zaginął. Do akt sprawy dołączony został list wysłany 22 lutego 1944 r. z obozu niemieckiego. W liście tym czytamy: „Wielce Szanowna Pani! Z przykrością, jednak z obowiązku zmuszony jestem podzielić się z Szanowną Panią smutną wiadomością. Otóż 18 lutego zmarł Jej syn major J.G. Pomimo starannej opieki nie udało się zmarłego utrzymać przy życiu. Rzeczy po ś. p. zmarłym zostaną przesłane drogą służbową. Jednakże ostatniego listu od Pani zmarły już nie czytał, gdyż nadszedł jeden dzień za późno"79.

Warto dodać, że do akt spraw, oprócz obozowej korespondencji stwierdzającej śmierć danej osoby, dołączane były też inne dokumenty stwierdzające jej zgon, które stanowiły dla sądu kluczowy środek dowodowy. Za przykład może posłużyć sprawa I Zg 38/50, z której wynika, że J.S. został w grudniu 1941 r. zabrany z mieszkania przez komendanta policji w Liszkach, niejakiego „Kruka”, i przewieziony do więzienia Sądu Okręgowego w Krakowie, a następnie do obozu koncentracyjnego w Oświęcimiu. W tej sprawie dołączono do akt zaświadczenie Biura Informacyjnego Polskiego Czerwonego Krzyża w Warszawie, w którym czytamy: „W odpowiedzi na zgłoszone poszukiwania J.S. zawiadamiamy, że w ewidencji strat wojennych prowadzonej przez Biuro Informacyjne Polskiego Czerwonego Krzyża w Warszawie figuruje J.S. urodzony 26 sierpnia 1912 r., który przebywał w obozie koncentracyjnymi, zmarł jako więzień nr $24397^{\prime \prime 80}$.W podobnej sprawie (I Zg 345/46) wnioskodawczyni domagała się stwierdzenia zgonu swojego męża F.A., który zginął podczas powstania warszawskiego. Wnioskodawczyni załączyła do wniosku zawiadomienie Zarządu Polskiego Czerwonego Krzyża z dnia 29 listopada 1945 r., które stwierdzało, że wspomniany F.A., pseudonim „Senator”, figuruje w prowadzonej ewidencji strat wojennych ${ }^{81}$. Z akt innej sprawy (I Zg 32/46) dowiadujemy się, że A.A. w maju 1942 r. podczas akcji przeciw ludności żydowskiej został wywieziony do Bełżca, skąd już nie wrócił. Dowodem w sprawie było poświadczenie Wojewódzkiej Żydowskiej Komisji Historycznej w Krakowie, stwierdzające na podstawie posiadanych dokumentów, w tym oryginalnego zarządzenia niemieckich władz okupacyjnych, że fakt wywiezienia A.A. do obozu w Bełżcu ponad wszelką wątpliwość równoznaczny był z faktem pozbawienia go życia ${ }^{82}$.

\footnotetext{
78 Postanowienie Sądu Grodzkiego w Krakowie z dnia 19 lutego 1950 r., sygn. I Zg 39/50.

79 Postanowienie Sądu Grodzkiego w Krakowie z dnia 1 marca1946 r., sygn. I Zg 89/47.

80 Postanowienie Sądu Grodzkiego w Krakowie z dnia 1 5lutego 1950 r., sygn. I Zg 38/50.

81 Postanowienie Sądu Grodzkiego w Krakowie z dnia 14 maja 1946 r., sygn. I Zg 345/46.

82 Postanowienie Sądu Grodzkiego w Krakowie z dnia 19 lutego 1946 r., sygn. I Zg 32/46.
} 
Środkiem dowodowym w omawianym postępowaniu były także prywatne dokumenty oraz rzeczy pochodzące od zaginionego, które mogły mieć zasadnicze znaczenie przy rozstrzyganiu omawianych spraw. Wśród dokumentów można wyróżnić dwie kategorie: dokumenty pochodzące od zaginionego - osoby, której zgon podlegał stwierdzeniu, oraz dokumenty, które pochodziły od innych osób. Szczególnie znaczenie miała ocena autentyczności dokumentów należących do zaginionego ${ }^{83}$. Przykładowo w Sądzie Grodzkim w Krakowie rozpatrywana była sprawa o sygn. I Zg 283/46, z której wynika, że S.D. złożyła wniosek o stwierdzenie zgonu swojego męża T.D. Wspomniany T.D. jako porucznik V pułku saperów brał czynny udział w działaniach wojennych. W 1939 r. dostał się do niewoli rosyjskiej, a następnie do obozu w Kozielsku. W 1943 r. jego nazwisko znalazło się na liście ofiar katyńskich. Potwierdzenie tej wiadomości dostała wnioskodawczyni od Czerwonego Krzyża z Warszawy, który wymienił zawartość znalezionych dowodów podczas ekshumacji w Katyniu. Na liście ekshumowanych ze zbiorowych polskich grobów w Katyniu przy T.D. były: dwa bilety kolejowe, świadectwo szczepienia, list, kartka pocztowa, legitymacja Urzędu Państwowego ${ }^{84}$. Z kolei w aktach sprawy o sygn. I Zg 86/46 czytamy, że żona wnioskodawcy R.B. została wywieziona z Krakowa do Tyńca i tam w lesie wraz z innymi ludźmi została zastrzelona przez Niemców i pochowana we wspólnym grobie. Ekshumacja i rozpoznanie zwłok zostało dokonane w obecności eksperta Starostwa Powiatowego w Krakowie. Starostwo Powiatowe zaświadczyło, że dnia 1 czerwca 1946 r. zostało wydane zezwolenie na ekshumację i przewiezienie zwłok śp. R.B. zamordowanej przez Niemców 8 czerwca 1943 r. na terenie gromady Tyniec i tam pochowanej. Ekshumacja odbyła się 2 czerwca 1946 r. w obecności członków rodziny i kontrolera sanitarnego J.K., delegowanego przez Starostwo Powiatowe. Zwłoki zostały zidentyfikowane po szczegółach ubrania oraz szczegółach budowy ciała. Ważnym elementem rozpoznawczym była obrączka ślubna znaleziona przy zwłokach, na której wyryta była data ślubu oraz imię męża ${ }^{85}$.

\section{ZAKOŃCZENIE}

Analiza uregulowań prawnych związanych ze stwierdzeniem zgonu prowadzi do wniosku, że przyjęcie przez polskiego ustawodawcę instytucji stwierdzenia zgonu było uzasadnione z dwóch powodów. Pierwszy stanowiła oczywista konieczność unifikacji prawa cywilnego, drugi natomiast - specyficzna sytuacja wynikająca

${ }^{83}$ S. Lizer, Cywilnoprawne formy eliminacji z materiatu dowodowego dokumentów sfatszowanych, Katowice 1975, s. 110.

${ }^{84}$ Postanowienie Sądu Grodzkiego w Krakowie z dnia 18 maja 1946 r., sygn. I Zg 283/46.

${ }^{85}$ Postanowienie Sądu Grodzkiego w Krakowie z dnia 10 lutego 1946 r., sygn. I Zg 86/46. 
z zakończenia II wojny światowej. Instytucja stwierdzenia zgonu zmierzała do uregulowania sytuacji prawnej osoby zmarłej, wobec której pomimo niewątpliwej śmierci akt zgonu nie został sporządzony. Postanowienie stwierdzające zgon wywoływało skutki rzeczywistej śmierci. Stwierdzenie zgonu miało szczególne znaczenie na gruncie prawa spadkowego i rodzinnego. Dopiero sądowe stwierdzenie śmierci i wydanie aktu zgonu przez urząd stanu cywilnego umożliwiało prawne uregulowanie spraw po zmarłym, np. przeprowadzenie postępowania spadkowego. Uzyskane w ramach badań wyniki oraz oparte na nich analizy potwierdziły tezę, że II wojna światowa to jeden z najtragiczniejszych epizodów w historii ludzkości. Liczba wniesionych spraw w badanym okresie świadczy o skali problemu. Analiza materiału źródłowego dowiodła, że ludzie spotykali się z ogromną brutalnością i obojętnością wobec cierpienia. Więźniowie przebywający w więzieniach, obozach koncentracyjnych i gettach znaleźli się na dnie egzystencji, gdy zawieszone zostają wszelkie prawa moralne i zanikają więzi zbiorowe. Oprócz wyczerpującej pracy świadomie pozbawiano tam bowiem ludzi godności. W takich miejscach człowiek był zniewolony przez obozową rzeczywistość i tracił nadzieję, że zdoła przeżyć tak dramatyczne wydarzenia. Świadczy o tym fragment akt o sygn. I Zg 87/46, w których czytamy: K.G., urodzony 28 lipca 1906 r. w Warszawie, zamieszkały w Krakowie, został w 1940 r. aresztowany przez niemiecką policję w Krakowie i osadzony w obozie w Oświęcimiu. W tym czasie wnioskodawczyni dostała ostatnią wiadomość listowną od męża. W liście tym mąż prosił ją, „by nie czyniła żadnych starań o jego zwolnienie, bo wszystko jest już stracone i żeby sama była ostrożna”. Po świętach Bożego Narodzenia w 1940 r. wnioskodawczyni otrzymała wiadomość, że jej mąż został rozstrzelany w obozie w Auschwitz ${ }^{86}$.

\section{PROCEEDINGS TO OBTAIN A DECLARATION OF DEATH IN LIGHT OF THE FILES OF THE MUNICIPAL COURT IN CRACOW BETWEEN 1945 AND 1950}

\section{Abstract}

The present publication presents declaration of death cases that were pending at the Municipal Court in Cracow between 1945 and 1950. The paper also concentrates on an analysis of the issues related to the procedure necessary to obtain a declaration of death in the Polish system of non-litigious proceedings in the post-war period.

Keyw ords: declaration of death, court files, Municipal Court in Cracow, World War II, court procedure

${ }^{86}$ Postanowienie Sądu Grodzkiego w Krakowie z dnia 24 lutego 1946 r., sygn. I Zg 87/46. 